\title{
The residence in the country of the target language and its influence to the writings of Greek learners of French
}

\author{
Zafeiroula Papadopoulou \\ Didactique des langues et des cultures, Université de la Sorbonne Nouvelle -Paris 3, \\ France \\ https://doi.org/10.36505/ExLing-2006/01/0043/000043
}

\begin{abstract}
The study of linguistic acquisition implies the study of the contexts where this process evolves. In order to analyze the role of the residence in the country of the target language, we formed two groups of informants (one in Greece, one in France). In order to make this comparison, we chose to analyze the reference to the entities and the temporal reference in the texts collected, and we hoped to show the influence of a residence in France.
\end{abstract}

\section{Rationale}

The aim of this research is to examine the relation between the references to the people and to the time and the textual cohesion in texts produced by various groups of script writers, by wondering about the independent variable "residence in the country of the target language".

\section{Theoretical base}

This research reposes to the model of the quaestio of Stutterheim and Klein (1991). The quaestio is the general/abstract question to which any text answers. The speaker, each time he constructs a narration, has to answer an implicit question having the general form "What happens to $\mathrm{P}$ then?" or "What does it occur to $\mathrm{P}$ at time T?" P representing the protagonists.

The quaestio exerts a constraint on the local level of the enunciation, into two parts: the topic (T) and the focus (F). The topic is that about which the speaker speaks, the support reference frame, and ensures the continuity of the text according to the rule of the repetition, while the focus is what one says of the topic, the contribution of information which brings new information, and ensures its progression

\section{Recueil of the corpus}

Our corpus is composed of narrations requested using extracts of two films. The first montage consists of eight photographs of the film "American pie".

ExLing 2006: Proceedings of 1st Tutorial and Research Workshop on Experimental Linguistics, 28-30 August 2006, Athens, Greece 
At the beginning a young man is looking at a girl, who is playing the flute, in front of whom a group of girls, in row, also play the flute. Once the concert is over, and the girls leave the scene, our hero decides to go and speak to the girl. When she notices him, she seems surprised.

The second series of photographs is an extract of the film "The pink panther". The scene takes place on the island Saint Louis in Paris, where a man exchanges something with a woman. Two police cars arrive, and the heroes start running. After entering a hotel, the woman enters the elevator surveyed by a monk and the receptionist. A police officer waits outside the elevator and the two other take the staircases. At the same time in the elevator, the woman changes her appearance. After that disguise, the policemen fail to stop the suspect woman.

The productions of two groups were collected, resulting 20 texts coming from: 10 Greek learners of French who never lived within a French-speaking community (G1) and 10 Greek learners of French who live at the time of the collection of the data in France (G2). It is necessary to add that French is not their second language but their third. All the informants speak already English.

\section{Analysis}

Let us come now to the results of our research: concerning the reference to the entities, we noticed entities to a position $\mathrm{T}$ or $\mathrm{F}$ during their introduction. Their position constitutes an indicator of the hierarchy of these entities in the two stories.

In the film American Pie, for the G1 the entities occupy a position $\mathrm{T}$ or $\mathrm{F}$ according to their appearance to the film. For the film Pink Panther, the police force is, most of the time in T position. Eight people treat the history as if the monk and the receptionist did not exist. An explanation could be the ignorance of the words monk and receptionist. Concerning the G2 the role of the protagonists is shared for two films.

As for the maintenance of the entities, a great percentage of substitution of the entities is made by a pronoun. The pronouns indicate mutually known entities and are used to avoid the repetition. In French, where the subject is obligatory, the maintenance of the reference is marked by a pronoun. In our study, we distinguish that the pronouns the most often used are the personal pronouns

Most of our informants (16/20) choose the possessive in order to maintain an entity. The possessive expresses various semantic relationships such as: property ( «sa robe »), characteristic ( «son apparence »), semantic roles associated to a process ( $«$ son attention ») as well as possession itself. 
The studies relating to the maintenance of the reference also show that the languages tend to mark the degree of accessibility to the entities by more or less explicit forms. In general, there is pluralism concerning the full forms which refer to the protagonists. By order of frequency the full forms used for the maintenance 'the young man', 'the girl' and 'girls' for the first history and 'the man', 'the woman', and 'the police officers', for the second one, are used massively to reintroduce a distant referent and to promote it to a $\mathrm{T}$ position.

Finally the reinforcement of cohesion is made by the co-presence of 2 or 3 entities within the same sentence or by the forms of recovery ' $c ̧ a$ ' or 'là'.

According to Klinger (2003) the cohesion of a text is ensured by the reference to the acting entities and by the temporal reference. Regarding the temporal reference in our corpus we observe the almost total dominance of present. And it is essential to mention that the subjects also express temporality through the grammatical and lexical aspect. Finally we have observed in the corpus temporal markers (connectors, prepositions) used to reinforce cohesion.

\section{Discussion}

Our study relates to advanced learners. Similar researches exist, for example, that of InterFra. As for the results of the project of InterFra, we could notice that our informers, like those of InterFra, acquire the rules of the verbal agreement. Another project is that of ESF (Klein W. \& Perdue C., 1997) where the learners manage to build phrases rich in progression and temporal returns. Our informers, according to their productions show a good use of verbal morphology; but it should not be forgotten that our informers follow or have already followed French courses in Greece.

Following Dabène (1990), we distinguish our groups according to their residence. The first group is the case of the exolingue situation, in other words they live in a country where another language that the TL, whereas the second group is the case of the endolingue situation. Our last objective consisted of making a comparative analysis between the two groups. We seize that the differences between the two groups relate to the sociolinguistic competences, the lexical level and the length of the accounts.

Research relating to advanced learners during a stay in the native community shows that as a whole, there is no spectacular development at the structural level. We have nevertheless, the impression that they have a benefit of the stay in the foreign country, in particular in the development of various aspects of the sociolinguistic capacities. We observe for example in our corpus, that six people out of ten, of the G2, identify the bridge of the island Saint Louis which is not the case for the G1. 
Moreover, we find enunciations which do not include characters. These enunciations reinforce the narrative, and they are used by the learners of the G2 who are more analytical in the description.

Another very interesting remark consists of the number of the temporal markers. The percentage of the G1 is much higher than that of the second group. The informers who live in Greece used in the 179 propositions 104 markers. However, in the 296 propositions of the second group, 82 markers were used. We can explain this phenomenon by the fact that the informers in Greece use more marks so as to explicate the temporal relations, while those in Paris, express these relations by verbal morphology and by the aspect (lexical and grammatical) At the lexical level also, there are differences between the two groups. If we observe their productions attentively, we understand that the group of Paris, use words which are not 'institutionally' taught like "le flic" (the cop), "la gendarmerie", "merde" (shit) and which are normally learned by listening to them.

\section{Conclusion}

In conclusion, the result of this research is that the residence in a native community is essential for the improvement of sociolinguistic and lexical competences, but only the exposure to the TL in the natural environment does not improve morphosyntaxic competence.

\section{References}

Clerc, St. 2003. L'acquisition des conduites narratives en français langue étrangère www.marges-linguistiques.com, 1-18.

Dabène, L. and Cicurel, F. and Lauga-Amid, M.-C. and Foerster, C. 1990. Variations et rituels en classe de langue, Paris, coll. LAL, Hatier Credif.

Juli, S. 2003. Comment se développe la morphologie verbale en français L2 chez les sinophones? www.marges-linguistiques.com, 1-13.

Klein, W. and Von Stutterheim, Ch. 1991. Text structure and referential movement. Arbeitsberichte des Forschungsprogramms Sprache und Pragmatik. Lund University.

Klinger, D. 2003. Raconter dans deux langues : traitement et fonction des connecteurs dans le cadre éxpositif et le déclenchement de la narration. Étude menée sur la production française (L2) et japonaise (L1) de deux locutrices japonophones, www.marges-linguistiques.com, pp. 1-14.

Lambert, M. 2003. Cohésion et connexité dans des récits d'enfant et d'apprenants polonophones du français, www.marges-linguistiques.com, 106-121. 